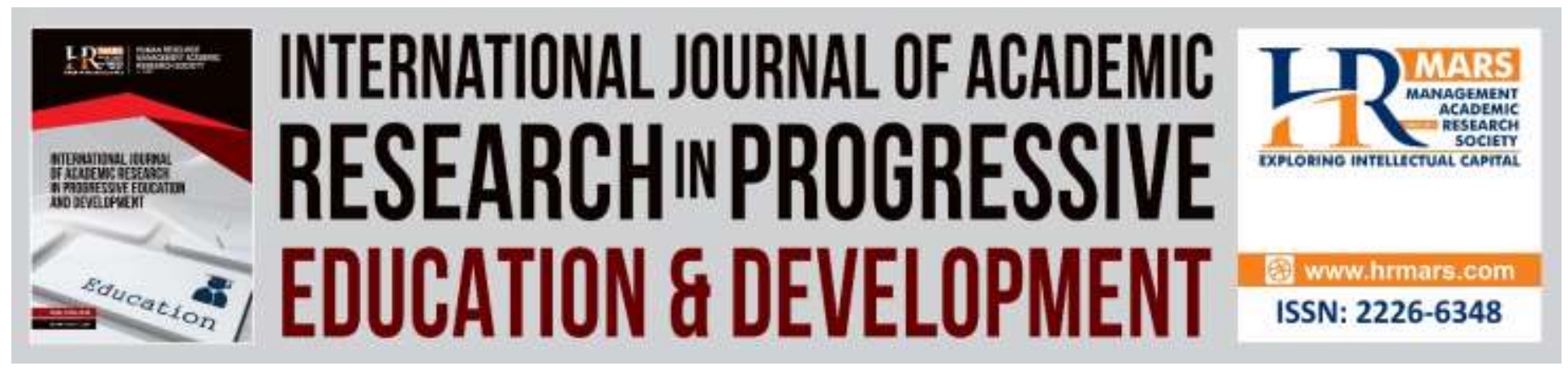

\title{
Translating ISTI'ARAH and Kinayah in Quranic Verses
}

\author{
Noor Eliza Abdul Rahman, Roslan Ab Rahman, Najmiah Omar, Siti Hajar \\ Mohamad Yusoff, Zulazhan Ab Halim, Muhammad Saiful Anuar Yusoff
}

To Link this Article: http://dx.doi.org/10.6007/IJARPED/v8-i4/6614

DOI:10.6007/IJARPED/v8-i4/6614

Received: 12 October 2019, Revised: 30 October 2019, Accepted: 10 November 2019

Published Online: 29 November 2019

In-Text Citation: (Rahma et al, 2019)

To Cite this Article: Rahman, N. E. A., Rahman, R. A., Omar, N., Yusoff, S. H. M., Halim, Z. A., Yusoff, M. S. A. (2019). Translating ISTI'ARAH and Kinayah in Quranic Verses. International Journal of Academic Research in Progressive Education and Development, 8(4), 502-515.

Copyright: (C) 2019 The Author(s)

Published by Human Resource Management Academic Research Society (www.hrmars.com)

This article is published under the Creative Commons Attribution (CC BY 4.0) license. Anyone may reproduce, distribute, translate and create derivative works of this article (for both commercial and non-commercial purposes), subject to full attribution to the original publication and authors. The full terms of this license may be seen at: http://creativecommons.org/licences/by/4.0/legalcode

Vol. 8(4) 2019, Pg. 502 - 515

http://hrmars.com/index.php/pages/detail/IJARPED

JOURNAL HOMEPAGE

Full Terms \& Conditions of access and use can be found at http://hrmars.com/index.php/pages/detail/publication-ethics 


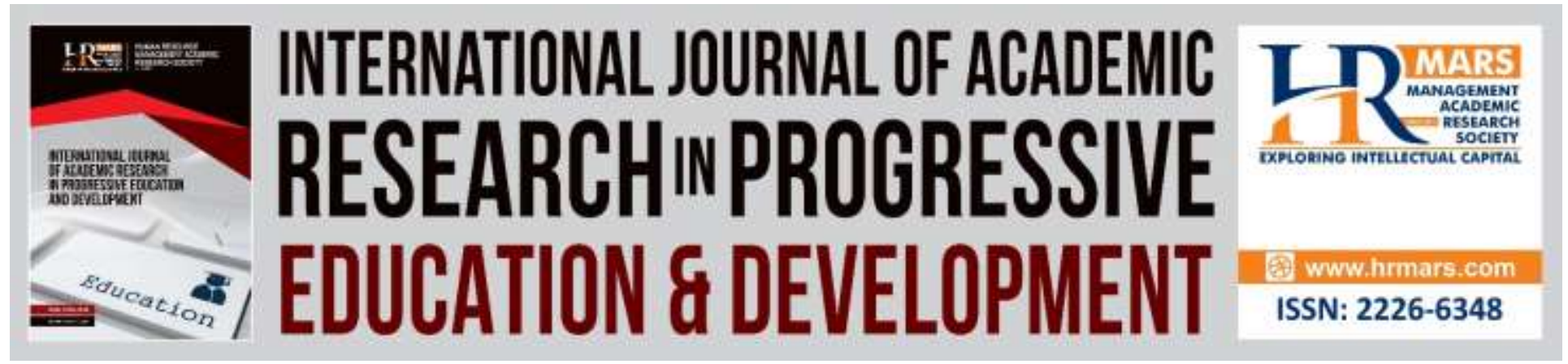

\title{
Translating ISTI'ARAH and Kinayah in Quranic Verses
}

\section{Noor Eliza Abdul Rahman, Roslan Ab Rahman, Najmiah Omar, Siti Hajar Mohamad Yusoff}

Faculty of Islamic Contemporary Studies, Universiti Sultan Zainal Abidin, Kuala Terengganu, Terengganu, MALAYSIA

\section{Zulazhan Ab Halim}

Faculty of Languages and Communication, Universiti Sultan Zainal Abidin, Kuala Terengganu, Terengganu, MALAYSIA

\author{
Muhammad Saiful Anuar Yusoff \\ Academy of Language Studies, Universiti Teknologi MARA, Kelantan, MALAYSIA
}

\begin{abstract}
Isti'arah and kinayah are among figurative expressions, commonly found in Arabic language. Isti'arah refers to the use of words which are not from its derivative meaning and the correlation between original meaning and majazi meaning based on the foundation of similarity. Kinayah, on the other hand, are words, which means beyond its literal meaning. Both elements are often discussed by scholars, especially in the study of Quran and Arabic Balaghah. The objective of this study is to identify strategies employed by Arab-Malay translators when dealing with both elements in Quranic verses, besides examining for the best translating strategies for expressions of isti'arah and kinayah. This study is qualitative in nature, using content analysis method. Data was collected from Tafsir Pimpinan al-Rahman, tafsir al-Haramain and Mushaf al-Farid. Five of each isti'arah and kinayah statements were selected to be analysed based on istiárah translating strategies, as proposed by Majdi (2009). The analysis of translating strategies is carried out by comparing translation in the three tafsir texts. Findings revealed that three strategies which are commonly used by translators are literal translating strategy, tafsir strategies and explanatory strategy through the use of footnotes. This study also found that expressions of istia'rah and kinayah should be best dealt through the use of literal translating and tafsir strategy while a combination of literal translating strategy and explanatory strategy are observed best when translating expressions of kinayah.
\end{abstract}

Keywords: Istia'rah, Kinayah, Translation, Translating Strategies. 


\section{Introduction}

Al-Quran is a holy manuscript which is the peak and closure to Allah's scriptures. It His special gift for His servants. It is filled with numerous invaluable knowledge, the ultimate wisdom and guidance which can show men to deal with life challenges. As a source of knowledge and wisdom, evidently the understanding of the content in the Al-Quran should be possessed and appreciated by mankind. Hence, the effort to translate the meaning of Al-Quran to other languages should be done meticulously so that its embedded messages can be understood correctly by all.

Al-Quran was revealed in Arabic language and features unique language characteristics and high rheotical elements. What it means by rhetorical element is the verses are figurative in nature or symbolical language which contain a different meaning from its original word such as tashbih, isti'arah, majaz mursal, kinayah, tajsid, mubalaghah and mathal. Besides figurative expression, this expression is also known as metaphors in translation books. Expressions such this at times, cannot be translated word by word because of the cultural and semantic difference between source language and target language. As such, this further challenges the effort to translate Quranic verses, which is filled with secrets and reasons for its revelation. Besides referring to tafsir manuscripts, translators must know the correct and suitable methods and strategies of translating when dealing with metaphors or figurative expressions in Al-Quran so that its messages can be transferred to the target language clearly and correctly.

\section{Objective and Research Method}

This study aims to examine translating strategies or methods employed in translating verses containing isti'arah and kinayah in Al-Quran. This study is qualitative in nature, which employed content analysis method. The corpus of the study are three Quranic translation texts, which are Tafsir Pimpinan al-Rahman, tafsir al-Haramain dan Mushaf al-Farid. This study only focused on translation containing verses with elements of isti'arah and kinayah. Besides that, it analysed the use of translating strategies by observing the correctness of meaning and message delivery in the translation.

\section{Definition of Isti'arah}

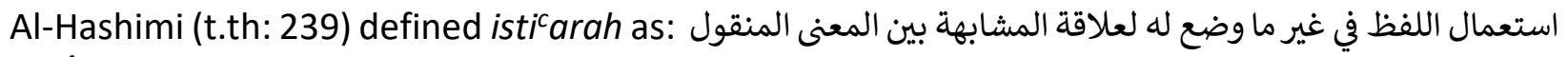
عنه والمعنى المستعمل فيه، مع قرينة صارفة عن إرادة المعنى الأصلي.

(Using the word does not necessary follow the original meaning because there is a mushabahah [similarity or equality] relationship between transferred meaning and original meaning, followed by the presence of qarinah (marker) which hinders the use of its original meaning).

According to Syukri et. al. (2012: 74), there is a range of definitions for isticarah based on terminology, nonetheless its meaning in general refers to the same basis as mentioned above. Between original meaning (or its hakiki meaning) and the hidden meaning lays a connection which is similar in nature. Isti'arah is majaz from the aspect of language use and appears to be tashbih, which only has one of the two main principles, which are comparative verbal (mushabbah) and compared verbal (mushabbah bih). At the same time, it is reduced of its characteristic (wajh al-shabah) to allow mushabbah and mushabbah bih, as well as a medium of comparison (adat al-tashbih). Because of that, tashbih is the basis for isticarah and isticarah is a branch of tashbih. 


\section{Definition of Kinayah}

لفظ أطلق وأريد به لازم معناه مع قرينة لا تمنع من According to al-Hashimi (t.th: 272), kinayah is defined as an expressed word with the intention to portray a different meaning, embedded within the word. Nonetheless, it could also refer to the actual meaning because of the absence of any marker that hinders from understanding the original meaning).

Kinayah refers to an understood oralization with connotative meaning. However, the language structure is also understood with its denotative meaning (Basir \& Syarah, 2018: 173). The use of kinayah can help users to indirectly use language which can be hurtful to others. Besides that, kinayah enables a literary user to describe what he intends without revealing himself to the risk, which could appear from using direct expression (Maqbul \& Dhikra, 1990: 506; Abdullahi, Rouyan, Noor, \& Halim, 2018).

\section{Definition of Strategy}

The word 'translating strategy' which is used in this analysis, originally refers to translating procedure. The word 'prosedure' can be defined as a common way to administer a matter, order or way of working or doing things (KamusDewan, 2007: 1235). In the context of translation, on the other hand, Newmark (1988: 81) explained that translating procedures are used to translate sentences and language units, smaller than clause and words. The word 'strategy' on the other hand, means "a plan that you use in order to achieve atau the act of planning how to do or achieve" (NewOxford Dictionary, 2012: 818). KamusDewan (2007: 1525) defined strategy as an organized plan to achieve a purpose or success.

Baker (1992: 7) highlighted, strategy refers to the ways to deal with difficulties during translating, which are analysis the overall of the text by using the strategy. Meanwhile Jaaskelainen (1991: 116) defined strategy as a set of rules or principles used by the translator to achieve the purpose determined by the translating situation in the most effective way possible.

Based on the earlier discussed definitions, the word 'strategy' refers to any well-thought and detailed planning to encounter problems and to achieve a particular purpose or objective, while the word 'procedure' on the other hand, only rerers to ways of doing something. In the context of studies on translation, the word 'strategy' is seen to be more suitable to be used as compared to the word 'procedure' in order to show that a certain action or effort is done to solve a problem, to deal with existing challenges during the process of translating and to achieve the intended purpose of the translating output.

\section{Strategies of Translating Figurative Expressions}

Majdi (2009: 104-109) suggested isti'arah translating strategy in his book entitled والترجمة بين العربية to be applied when translating figurative language in the Malay and Arabic language. These strategies is said as أساليب ترجمة الاستعارة. He also expressed that these strategies are not simply to be benefitted in isticarah translation only, but can be also be used when translating other figurative forms like majaz mursal, kinayah, mathal and others. These strategies are: 


\section{Literal Translating Strategy}

This strategy means the effort of translating source figurative language to target language by using harfiah translation or word by work translation or literal translation. This translating process is carried out by suggesting words of the target language with the same denotative meaning as the words of the source language. The use of this strategy is however, conditioned that the word used has the same meaning and message as the target language. For example, the phrase ماء الوجه is translated as air muka (meaning water face) and شهو العسل is translated as bulan madu (meaning honeymoon) (Bukhari, 1993).

\section{Replacement Strategy}

This strategy means the effort of replacing the image in the source language with an familiar image used in the target language, which does not contradict with the culture of the target language (Newmark, 1992: 138). In another word, replacing a figurative expression in the source language with a figurative expression in the target language that might be different in its oralization but has the same meaning or understanding. This strategy is used when literal translating is not suitable or seems to be awkward in the target language. Hence, translators are allowed to find figurative images in the target language, which has the same understanding and allow the delivery of the intended message in the source text. For example, the application of this strategy is seen in translating Arabic proverbs, which is يمسي على حر ويصبح على بارد which means dia berpanas pada waktu petang dan bersejuk pada waktu pagi (meaning he struggled in the afternoon while relaxes in the morning). This Arabic proverb is translated into a Malay proverb as hangat-hangat tahi ayam (meaning casual invitation) (Azmi, 2013: 198; Tyasari, Yusof, Bahador, 2018).

\section{Tafsir Strategy}

This strategy is carried out by adding an elaborate explanation to the figurative element that requires explaining. According to Asmah (2009: 110), transfering information from one text to another language in the form of explanation is done through paraphrasing and illustrasion about its meaning, known as tafsir. Hence, the terminology of tafsir strategy is used in reference of this strategy.

Translators can use this strategy when observing the ineffectiveness and lack of clarity using قراءة الكف مu replacement strategy (Saifulah et al., 2012: 189). For example, the figurative expression is translated to the phrase menilik perkara ghaib (meaning to observe the unseen) (Othman 2012: 109). The phrase goyang kaki (meaning shake your legs) on the other hand, is translated to لايفعل شيئl (Majdi, 2009: 107).

\section{Simile Strategy}

This method can ease the difficulty of finding a isti'arah matching, besides retaining its original structure. This is because simile is far easier to be understood in comparison to metaphors or 
INTERNATIONAL JOURNAL OF ACADEMIC RESEARCH IN PROGRESSIVE EDUCATION AND DEVELOPMENT

Vol. 8, No. 4, 2019, E-ISSN: 2226-6348 C 2019 HRMARS

other figurative expressions. For example, the use of this strategy can be seen in translating alKahfi, verse 99:

On that day, We let them fight among themselves like waves of the ocean that counter-act with one another (Nasimah \& Lubna, 2016).

\section{Omission Strategy}

By using this method, figurative forms which exists in texts are not translated to the target language. Translators can omit figurative expressions in the text, with the condition that such figurative expression is an added element that is without any meaning in the text (Majdi, 2009: 109). According to Newmark (1992: 141), if the metaphor in the text is not important, it is advisable to omit it, with the condition that the text from the source language is not the form of announcement or conveying information.

\section{Explanatory Strategy}

Translators often deal with figurative expression at the level of katawi atau literal, who then provide explanation and elaboration in the form of footnotes. For example, the translation of alIsra', verse 29:

Meaning:

And you shall not cause your hands to be strangled to your neck, and you shall not extend it to its ends, because the results will leave you in the most despicable and wretchedness.

This verse was given explanation to its translation in the footnote section as Jangan kamu terlalu kikir, dan jangan pula terlalu pemurah (Meaning Don't you aim at being stingy nor at being too generous) (Majdi, 2009: 108).

\section{Data Analysis \\ Data on ISTI'ARAH}

EXAMPLE 1

(al-Baqarah: 187)

The istia'rah expression: (الخيط الأبيض ، الخيط الأسود)

The true meaning of الخيط الأبيض is white thread while الخيط الأسود means the black thread. Both phrases did not use its exact meaning in the verse because white and black threads cannot determine the duration of fasting. Both expressions are istia'rah which symbolizes the whiteness of daylight similar to a white thread while the darkness and blackness of night alike the black thread. The given translation to this phrase is as follow: 
INTERNATIONAL JOURNAL OF ACADEMIC RESEARCH IN PROGRESSIVE EDUCATION AND DEVELOPMENT

Vol. 8, No. 4, 2019, E-ISSN: 2226-6348 @ 2019 HRMARS

Table 1

\begin{tabular}{|c|c|c|}
\hline Tafsir Pimpinan al-Rahman & Tafsir al-Haramain & Mushaf al-Farid \\
\hline $\begin{array}{l}\text { And so eat and drink until it is } \\
\text { clear to you between the } \\
\text { white thread (daylight) and } \\
\text { black thread (the darkness of } \\
\text { night), which is the dawn. }\end{array}$ & $\begin{array}{l}\text { Eat and drink until it is clear to } \\
\text { you (of the difference) } \\
\text { between the white thread } \\
\text { and black thread, which is } \\
\text { dawn. }\end{array}$ & $\begin{array}{l}\text { And eat and drink until it is } \\
\text { clear for you the white thread } \\
\text { and black thread. }\end{array}$ \\
\hline
\end{tabular}

Tafsir Pimpinan Al-Rahman translated the phrase as the 'white thread' and 'black thread'. In the same tafsir too, the phrase was given translation along with brackets to the explanation 'daylight' and 'the darkness of night'. This is called literal translating strategy and tafsir strategy. Tafsir al-Haramain and Mushaf al Farid on the other hand, used literal translating strategy by only providing harfiah translation, which is 'white thread' and 'black thread'. The translation given in Tafsir Pimpinan al-Rahman can be perceived as able to give clear understanding and delivers the meaning of the verse to the target readers.

Example 2

(al-Baqarah: 16)

الشتروا الضلالة بالهدى:اsti'arah expression: (

In this verse, oralization (اشتروا) is isti'arah and used not with its original meaning, which is to 'buy' something. This is because الضلالة and are two abstract words and cannot be combined with the act of selling or purchasing. In this expression, the exchange is compared to buying. AlZamakhsyari (1987:69) explained that اشتراء الضلالة بالهدى is isti'arah which means to choose, hence replacing lost with guidance. The given translation to this phrase is as follow:

Table 2

\begin{tabular}{|c|c|l|}
\hline Tafsir Pimpinan al-Rahman & \multicolumn{1}{|c|}{ Tafsir al-Haramain } & \multicolumn{1}{c|}{ Mushaf al-Farid } \\
\hline $\begin{array}{l}\text { Those are people who buy } \\
\text { digression and left guidance. }\end{array}$ & $\begin{array}{l}\text { They are those who buy } \\
\text { digression with guidance. }\end{array}$ & $\begin{array}{l}\text { They are those who buy } \\
\text { digression with guidance }\end{array}$ \\
\hline
\end{tabular}

All three translations above show the employment of literal translating strategy when translating the figurative expression. The translators retained the original meaning of the word, which is an isti' arah because this matching is able to clarify meaning and convey the message of the verse to the target readers.

Example 3:

(al-Baqarah: 245)

Isti'arah expression: يقرض الله.

The word أقرض- يقرض - قرض means to give loan. (Kamus Besar Arab-Melayu Dewan 2006: 1860). According to al-Zamakhsyari (1987: 290), the expression يقرض الله which means 'giving loan to Allah' employs the element of comparison. Doing good deeds with the hope that it shall be rewarded from Allah can be understood as giving load to Allah. The given translation to the phrase is as follow: 
INTERNATIONAL JOURNAL OF ACADEMIC RESEARCH IN PROGRESSIVE EDUCATION AND DEVELOPMENT

Vol. 8, No. 4, 2019, E-ISSN: 2226-6348 @ 2019 HRMARS

Table 3

\begin{tabular}{|l|l|l|}
\hline \multicolumn{1}{|c|}{$\begin{array}{c}\text { Translation by Abdullah } \\
\text { Basmeih }\end{array}$} & \multicolumn{1}{|c|}{ Tafsir al-Haramain } & \multicolumn{1}{c|}{ Mushaf al-Farid } \\
\hline $\begin{array}{l}\text { Who among those who are } \\
\text { (willing) to give loan to Allah as } \\
\text { a good promise. }\end{array}$ & $\begin{array}{l}\text { Whoever gives to Allah } \\
\text { an } \text { with }\end{array}$ & $\begin{array}{l}\text { Who among those who } \\
\text { has something (willing) } \\
\text { to give loan to Allah (to } \\
\text { give away his property in } \\
\text { the path of Allah). }\end{array}$ \\
\hline
\end{tabular}

Based on the above translations, all three texts matched 'giving loan' or 'loaning' to elements of isti'arah. Literal translating strategy was used in all three translations upon dealing with the elemnt of isti'arah. Although Tafsir al-Haramain combined two strategies, which are literal translating strategy and explanatory strategy through the use of footnote, which clearly explains the true meaning of the expression 'to loan' as 'to give alms in path of Allah'. Mushaf al-Farid on the other hand combined literal translating strategy and tafsir strategy by providing bracketed explanation (to give away his property in the path of Allah). Both translations are perceived as enabling the correct understanding and delivery of message within the verse to the target readers.

Example 4:

(al-Israa': 12)

جناح الذل جsti'arah expression

The word جناح means wings and the word الذل means disgrace (Kamus Besar Arab-Melayu Dewan 2006: 348, 822). Humility is compared to a bird, mushabbah bih is omitted and made as a symbol of a common characteristics of a bird, which is the wing (Wahid et. al 2016: 295). The given translation to the phrase is as follow:

Table 4

\begin{tabular}{|l|l|l|}
\hline Tafsir Pimpinan al-Rahman & \multicolumn{1}{|c|}{ Tafsir al-Haramain } & \multicolumn{1}{c|}{ Mushaf al-Farid } \\
\hline $\begin{array}{l}\text { And you shall humble } \\
\text { yourself to the both because } \\
\text { of your love and mercy. }\end{array}$ & $\begin{array}{l}\text { And give service to the two } \\
\text { with love. }\end{array}$ & $\begin{array}{l}\text { And humble yourself to the } \\
\text { two with all humility. }\end{array}$ \\
\hline
\end{tabular}

Based on the above translation, it can be observed that Tafsir Pimpinan al-Rahman and Mushaf al-Farid did not provide a matching for the phrase جناح الذل. Figurative Omission strategy was used by Tafsir Pimpinan al-Rahman and Mushaf al-Farid upon dealing with the isti'arah expression. جناح الذل. Meanwhile, Tafsir al-Haramain provided a match of 'give service' to the expression. This translation used tafsir strategy by providing the understanding within the isti'arah. Nevertheless, this matching is perceived to be inaccurate. The translations provided by Tafsir Pimpinan al-Rahman and Tafsir al-Haramain are observed to have been able to give understanding and delivered the meaning of the verse to the target readers.

Example 5:

(al-Haqqah: 11)

Isti'arah expression: طغا الماء. 
Vol. 8, No. 4, 2019, E-ISSN: 2226-6348 @ 2019 HRMARS

The word bil means to transcend (Kamus Besar Arab-Melayu Dewan 2006: 1450). This expression contains figurative meaning because water is not comparable to the act of transcendence. Here, overflow is compared to the act of exaggeration. Accordint to Qatadah (alQurtubi: 243) the water level which drowned the place of the people of Nuh was as deep as 15 hasta (arm's length) from the water surface. The word طنى was used to indicate how deep the water which drowned the place of the people of Nuh. The given translation to the phrase is as follow:

Table 5

\begin{tabular}{|c|c|c|}
\hline Tafsir Pimpinan al-Rahman & Tafsir al-Haramain & Mushaf al-Farid \\
\hline $\begin{array}{l}\text { Verily We - when the flood } \\
\text { exaggerated its limits (and } \\
\text { drowned the mountains) - } \\
\text { packed and saved your } \\
\text { anchestors to the Nuh ship. }\end{array}$ & $\begin{array}{l}\text { Verily when the water rose } \\
\text { (till the mountains) We took } \\
\text { your anchestors into the Nuh } \\
\text { ship. }\end{array}$ & $\begin{array}{l}\text { Verily when the water rose } \\
\text { (to the mountains) we } \\
\text { brought your anchestors into } \\
\text { the ship. }\end{array}$ \\
\hline
\end{tabular}

The above translations show Tafsir Pimpinan al-Rahman translated the expression by using 'exaggerating its limits'. The translator used literal translating strategy by providing a match of meaning that was given in the dictionary, which is exaggerating. Meanwhile Tafsir al-Haramain and Mushaf Farid provided a matching of 'water rose till the mountain'. The translator employed tafsir strategy by providing hidden meaning within the isti'arah. This translation is seen as better since it is able to provide correct understanding and conveyed meaning of the verse to the target readers.

\section{Data on Kinayah}

Example 1:

(Al-Qamar: 13)

The word ألواح is a plural word for لوح which means wide pieces of either wood, bone, etc. (Kamus Besar Arab-Melayu Dewan, 2006: 2139). The word دسر on the other hand is a plural form for دسار which means nail or rope that is used to strengthen certain parts of the ship (Kamus Besar Dewan, 2006: 737). This oralization is considered as kinayah mawsuf, making relation to a ship. According to Musa (1993:418), this verse shows Allah's portrayal of man's weakness when he is given misfortune and life test. The given translation for this phrase is as follow:

Table 6

\begin{tabular}{|l|l|l|}
\hline Tafsir Pimpinan al-Rahman & \multicolumn{1}{|c|}{ Tafsir al-Haramain } & \multicolumn{1}{c|}{ Mushaf al-Farid } \\
\hline $\begin{array}{l}\text { And We carry Nuh and his } \\
\text { followers onto (the built ship) } \\
\text { from pieces of wood and } \\
\text { nails. }\end{array}$ & $\begin{array}{l}\text { And We carry him (Nuh) onto } \\
\text { wood and nails. }\end{array}$ & $\begin{array}{l}\text { And We carry him (Nuh) onto } \\
\text { (the ship) made from wood } \\
\text { and pegs. }\end{array}$ \\
\hline
\end{tabular}

Based on the given translation, it is observable that all three texts translated the phrase as ship and added on explanation 'built or made from wood and nails'. The employed translation 
Vol. 8, No. 4, 2019, E-ISSN: 2226-6348 ㄷ 2019 HRMARS

strategy here is tafsir strategy which forwards hidden meaning of the kinayah phrase. These translation is assumed to be able to deliver the meaning of the verse.

Example 2:

(al-Saaffaat: 48)

Kinayah Expression: قاصرات الطرف.

The word قاصرات means a shy woman with protected gaze (Kamus Besar Arab-Melayu Dewan, 2006: 1885). According to IbnAshur (1997: 11/114), the phrase carries the understanding of lowering the gaze, which is kinayah that is 'iffah in its characteristics (protecting ones' dignity). The given translation for this phrase is as follow:

Table 7

\begin{tabular}{|l|l|l|}
\hline \multicolumn{1}{|c|}{ Tafsir Pimpinan al-Rahman } & \multicolumn{1}{|c|}{ Tafsir al-Haramain } & \multicolumn{1}{|c|}{ Mushafal-Farid } \\
\hline $\begin{array}{l}\text { While accompanying them } \\
\text { are maidens whose focused } \\
\text { gaze are only on them, which } \\
\text { are wide in their eyes.. }\end{array}$ & $\begin{array}{l}\text { (maidens) with big and } \\
\text { beautiful eyes and limited } \\
\text { gaze. }\end{array}$ & $\begin{array}{l}\text { And by theirs are maidens } \\
\text { with wide eyes and limited } \\
\text { gaze (except for their } \\
\text { husbands). }\end{array}$ \\
\hline
\end{tabular}

The above table shows all three translation texts provided the matching of 'maiden with limited or focused gaze' to the phrase. The chose translating strategy here is literal translating strategy because the translators employed denotative meaning for the phrase as provided in the dictionary. The translators did not explain the hidden meaning of the kinayah expression, which is to protect self-respect. The translations can be understood but not the true meaning of the expression.

Example 3:

(al-Sad: 33)

Kinayah Expression: مسحا بالسوق والأعناق

The word مسح - يمسح - مسح - means to fondle and to caress (Kamus Besar Arab-Melayu Dewan, 2006: 2201). In this verse, the oralization of مسح is used with a kinayah meaning. Al-Baydawi (2003: 312) explained that on the surface, the verse means Sulaiman's hand touched (sweep) the thigh and neck of the horse, but the hidden meaning is Sulaiman tied the horse's thigh and slaughtered its neck. His obsession with the horse caused him to perform his solat at the wee hour that caused the slaughtering of the horse. The verb 'to slaughter' is repaced with sweep as a show of respect and love for the horse (Abdul Basir \& Ummi Syarah, 2018: 178). The given translations for the phrase are as follow: 
INTERNATIONAL JOURNAL OF ACADEMIC RESEARCH IN PROGRESSIVE EDUCATION AND DEVELOPMENT

Vol. 8, No. 4, 2019, E-ISSN: 2226-6348 @ 2019 HRMARS

Table 8

\begin{tabular}{|l|l|l|}
\hline Tafsir Pimpinan al-Rahman & \multicolumn{1}{|c|}{ Tafsir al-Haramain } & \multicolumn{1}{c|}{ Mushaf al-Farid } \\
\hline $\begin{array}{l}\text { (Then Sulaiman said to his } \\
\text { people: "Bring back the horse } \\
\text { to me", so he moved forward } \\
\text { caress the thigh and neck of } \\
\text { the horse (one by one). }{ }^{1527}\end{array}$ & $\begin{array}{l}\text { me." So he fondled the leg } \\
\text { and neck of the horse."752 }\end{array}$ & $\begin{array}{l}\text { "Bring all the horses to me". } \\
\text { The he flaughtered its leg and } \\
\text { neck of the horse. }\end{array}$ \\
$\begin{array}{l}\text { Marking it as a form of } \\
\text { neck. }\end{array}$ & \\
$\begin{array}{l}\text { sacrifice to obtain Allah's } \\
\text { redha as a kaffarah to } \\
\text { eliminate his sins for slacking. }\end{array}$ & & \\
\hline
\end{tabular}

From the discussed translations, the three texts provided a match of 'fondling' or 'caressing' to the kinayah expression. The translators employed literal translating strategy in translating this kinayah expression. Tafsir Pimpinan al-Rahman and tafsir al-Haramain also used explanatory strategy by using a footnote. The given explanation in the footnote in Tafsir al-Haramain was able convey the underlying meaning of the kinayah expression which is the elaboration of 'slaughtering its leg and neck'. However, the footnote which explained the meaning of the verse in Tafsir Pimpinan al-Rahman can be observed to unclear and is not able to convey the meaning of the kinayah expression.

Example 4:

(al-Maaidah: 64)

Kinayah Expression: يد الله مغلولة غئو

The word غل - غيغل - غلا gives the meaning of to chain the hands or neck (Kamus Besar ArabMelayu Dewan, 2006: 1695). The oralization of مغلولة is an isim fail to غلّ which means to be tied up or chained. If it is translated using harfiah, this phrase means 'Allah's Hands are chained or tied up'. According to al-Alusi (1994: 6/264), the hand is kinayah to the provision and recipient of Grace. While ghull is a situation which prohibits grace from reaching the rightful. Therefore, this phrase is considered as kinayah to the being stingy or misery. The given translation to the phrase is as follow:

Table 9

\begin{tabular}{|l|c|c|}
\hline \multicolumn{1}{|c|}{ Tafsir Pimpinan al-Rahman } & Tafsir al-Haramain & Mushaf al-Farid \\
\hline $\begin{array}{l}\text { And the Jews said, "Allahs's } \\
\text { Hands are chained (stingy- } \\
\text { misery), their hands are } \\
\text { chained. }\end{array}$ & $\begin{array}{l}\text { And the Jews said, "Allah's } \\
\text { are chained". Verily, it is their } \\
\text { hands that are chained. }{ }^{285}\end{array}$ & $\begin{array}{c}\text { The Jews said, "Allah's Hands } \\
\text { are chained (as a sarcasm to } \\
\text { Allah)", when actually it is } \\
\text { their hands that are chained. } \\
\text { Its meaning is stingy (misery). }\end{array}$ \\
\hline
\end{tabular}

All three translations above show this kinayah phrase were translated using literal translating strategy by matching the saying of 'The Hands of Allah are bounded'. Tafsir Pimpinan al-Rahman 
also combined tafsir strategy along with literal translating strategy when dealing with this figurative expression which is to provide the figurative of 'bounded hands' to 'being stingy' in brackets. Similarly, Tafsir al-Haramain also combined literal translating strategy with explanatory strategy through the use of footnote. The use of both strategies for this translation can be assumed to have enabled clear delivery of meaning of the verse to the target readers.

Example 10

(al-Baqarah :187)

Kinayah Expression: رفث

The word رفث - يرفث - رفثا - رفوثا means to talk dirty (Kamus Besar Arab-Melayu Dewan, 2006: 929). The meaning of talking dirty here are words that are not pleasant to listen to such as vulgarity and can cause syahwat (Ibn Manzur, 2003: 4/193). This oralization is considered as kinayah for intercourse because there are indicators in the phrase, which is "It is permitted to you during the nights of Ramadhan". The given translation for this phrase is as follow:

Table 10

\begin{tabular}{|c|c|c|}
\hline Tafsir Pimpinan al-Rahman & Tafsir al-Haramain & Mushaf al-Farid \\
\hline $\begin{array}{l}\text { It is permissible for you during } \\
\text { the nights of fasting month to } \\
\text { mingle (have intercourse) } \\
\text { with your wives. }\end{array}$ & $\begin{array}{l}\text { It is permissible for you to } \\
\text { mingle with your wife during } \\
\text { the nights of fasting. }\end{array}$ & $\begin{array}{l}\text { It is permissibleyou're your } \\
\text { during the nights of fasting to } \\
\text { mingle (have intercourse) } \\
\text { with your wife. }\end{array}$ \\
\hline
\end{tabular}

Based on the above translation, it is observable that the word الرفث was translated as 'to mingle' and "to have intercourse". All three translations employed tafsir strategy in translating this kinayah expression. The use of this strategy is observed to be able to provide clear understanding and deliver meaning of the verse to the target readers.

RESULT FINDINGS

When translating figurative expressions in al-Quran, isti'arah and kinayah expressions are dealt by using several translating strategies, which are literal translating strategy, tafsir strategy, explanatory strategy and figurative omission strategy. The analysis showed replacing target figurative strategy is not used when translating these two figurative elements. There are three translating strategies which are commonly used by translators when dealing with isti'arah and kinayah expressions in the Quranic text, which are the literal translating strategy, tafsir strategy and explanatory strategy.

Based on the analysis, it is observed that literal translating strategy ensures precise translation without derailing from the original meaning. The use of explanatory and tafsir strategies, on the other hand, enables delivering the true meaning because Quranic verses an extensive understanding and often embedded, which occasionally cannot be understood by using harfiah translation.

Some expressions of isti'arah and kinayah can be translated using literal translation when the expression is general in nature and can be understood or used in the target language, hence providing a similarity between two comparable things in both source language and target language. For example, the literal translation of "borrowing Allah", "to purchase astray", and 
"exaggerated water" can deliver the message of the verse to the target readers. However, for expressions with cultural elements of the source language and seem to lack compatible images in the target language, such expressions usually require translators to use tafsir and explanatory strategies. Literal translation such as "having wood and nail", "limiting gaze", and "chained hands" cannot be understood of its true meaning unless it is given tafsir or explanation. The use of literal translating strategy which is combined with tafsir strategy or explanatory strategy by using footnote are considered as the safest step when translating figurative expression in alQuran, especially kinayah expressions. On that same note, the use of replacement strategy when translating Quranic texts should be avoided because it might cause mistakes when understanding al-Quran.

\section{Conclusion}

In brief, in the context of this study, in general, the expression of isti'arah and kinayah included in Al-Quran was dealt well by the translator. The choice for an apt translating strategy is important to ensure messages was conveyed to the target readers and to avoid miscomprehension of the Quranic verses. Literal translation (or known as harfiah) can sometimes fail to convey the messages, however translation which are too liberal or communicative can also produce translations which are derailed from its true meaning. Hence, the process of transferring meaning or translating Quranic verses to other languages should be done with great sense of wisdom, trust, responsibility and care so that the Allah's Holy Book is understood clearly.

\section{Acknowledgments}

We express our deepest gratitude to Malaysian Ministry of Education and Centre for Research Excellence \& Incubation Management (CREIM), UniSZA, Malaysia for supporting this publication.

\section{Corresponding Author}

Noor Eliza Abdul Rahman, Ph.D, is a lecturer at Department of Education, Dakwah \& Islamic Civilization, Faculty of Islamic Contemporary Studies, Universiti Sultan Zainal Abidin (UniSZA), Kampus Gong Badak, 21300 Kuala Nerus. Terengganu, Malaysia.

Email: nooreliza@unisza.edu.my

\section{References}

Abdullah, N., \& Rahman, L. A. (2016). Terjemahan ayat figuratif dalam al-Quran: perbandingan antara penterjemah individu dan berkumpulan. Jurnal KUIS.

Abdullahi, A., Rouyan, N. B. M., Noor, S. S. binti M., \& Halim, Z. bin A. (2018). Sentence Construction Errors among Malay Arabic Learners at Universiti Sultan Zainal Abidin. International Journal of Academic Research in Business and Social Sciences, 8(6), 953-966.

AbuMusa, M. (1993). Al-Taswir al-bayani dirasah tahliliyyah li masail al-bayan. Ctk.3. Kaherah: Maktabah Wahbah.

Ahmad, A. (2013). Hubungan rentas budaya dalam penterjemahan Arab-Melayu. Prosiding Penterjemahan Antarabangsa Ke-14, 192 - 206.

Al-Alusi, S. D. (n.d.). Ruh al-Ma'ani fi al-tafsir al-Quran al-azim wa al-sab' al-mathani. Tashih Muhammad Husain al-Arab. Beirut: Dar Ihya' al-Turath al-Arabi. 
INTERNATIONAL JOURNAL OF ACADEMIC RESEARCH IN PROGRESSIVE EDUCATION AND DEVELOPMENT

Vol. 8, No. 4, 2019, E-ISSN: 2226-6348 @ 2019 HRMARS

Al-Baydawi, A.A. (2003). Tafsir al-baydawi al-musamma anwar al-tanzil wa asrar al-takwil. Beirut: Dar al-Kutub al-IImiyyah.

Al-Haramain Tafsir Ringkas Ayat-Ayat Pilihan. (2013). Selangor: Karya Bestari Sdn. Bhd.

Al-Hashimi, S.A. (n.d.). Jawahir al-Balaghah fi al-Macani wa al-Bayan wa al-Badic. Edisi ke-6. Beirut: Dar al-Kutub al-'llmiyyah.

Al-Qurtubi, A. A. (n.d.) Al-Jami' li ahkam al-Quran. N.p: Dar al-Fikri.

Al-Zamakhsyari, M. (1987). Al-Kashshaf and baqa'iq al-tanzil wa 'uyun al-aqawil fi wujuh altakwil. Cet.3. Cairo: Dar al-Rayyan.

Awang, A. B. \& Ismail, U. S. (2018). Faktor kepenggunaan kinayah dalam al-Quran al-Karim. Jurnal e-Academia. 171-180.

Baker, M. (1992). In Other Words: A Coursebook on Translation. London \& New York: Routledge. Ibn`Ashur, M. T. (1984). Tafsir al-tahrir wa al-tanwir. Tunisia: Dar al-Tunisiyyahli al-Nashr.

Ibrahim, M. (2009). al-Tarjamah bayna al-'Arabiyyah wa al-Malayuwiyyah: Al-Nazariyyat wa alMabadi'. Kuala Lumpur: IIUM Press.

Jaaskelainen, R. (1991). Investigating translation strategies. Dlm. Tirkkonen-Condit, S. (pnyt.). Selected Paper on the TRANSIF Seminar, Savonlinna 1988. Tubinger: Narr.

Kamus Dewan. (2007). Edisi ke-4. Kuala Lumpur. Dewan Bahasa dan Pustaka.

Lubis, M. B. (1993). Menerjemahkan idiom Arab ke bahasa Melayu: beberapa pengamatan. Kertas kerja Seminar Terjemahan Arab-Melayu, Universiti Kebangsaan Malaysia, 27-29 Ogos.

Maqbul, S. H. U., \& Dhikra, A. M. M. (1990). al-Adab wa Al-Nusus wa al-Balaghah. Jil. 1. Libya: Dar al-Kutub al-Wataniyyah.

Mushaf al-Farid Terjemahan Bertulis Jawi dan Perkata. (2017). Kuala Lumpur: Rimbunan Islamik Media Sdn. Bhd.

Newmark, P. (1988). A Textbook of Translation. New York London: Prentice Hall.

Newmark, P. (1992). Pendekatan penterjemahan. Terj. Zainab Ahmad \& Zaiton Ab. Rahman. Kuala Lumpur: Dewan Bahasa \& Pustaka.

Omar, A. (2009). Penterjemahan pemindahan sistem semiotik. Jurnal Penterjemah 2: 107-119.

Othman, M. S. (2012). Memahami faktor budaya dalam penterjemahan bahasa. Prosiding Nadwah Bahasa dan Kesusasteraan Arab Ke-3, hlm 108-110.

Salleh, A. W., Abdullah, M. S., Omar, L., A.Latif, A. Z., Baioumy, N.A. A. Ab. Rahman, R. (2016). alBalaghah al-wafiyah: Ilmu balaghah lengkap (ma'ani, bayan dan badi'). Selangor: Darul Syakir Enterprise.

Samsudin, S., Jumingan, M. F., Hassan, A. R. \& Ismail, M. Z. (2012). Terjemahan metafora dalam hadis rasulullah s.a.w. Prosiding Nadwah Bahasa dan Kesusasteraan Arab Ke 3, 187-192.

Shaykhun, M. S. (1990). Al-Balaghah Al-Wafiyah. Kaherah: Maktabah al-Kuliyyat al-Azhariyyah. Tafsir Pimpinan al-Rahman Kepada Pengertian al-Quran. (n.d.). Kuala Lumpur: Darul Fikir.

Tyasari, I., Yusof, N. Z. M., Bahador, K. M. (2018). Indonesia's Participation in ASEAN Audit Regulators Group (AARG): Efficiency-driven or Institutional Pressure? International Journal of Academic Research in Accounting, Finance and Management Sciences 8 (3): 299-309. 